\title{
Political Practices of Ukrainian Muslims: Between the Apolitical and the Radical
}

\author{
Denys Brylov \\ National Pedagogical Dragomanov University
}

\begin{abstract}
The article examines the political practices of Ukrainian Muslims. It covers three main streams of political behavior: a) predominantly apolitical Islam of Muslim organizations connected with the transnational Sufi movement Al-Ahbash, b) political activism of Muslim organizations connected with the global Muslim Brotherhood network, c) radical (jihadist) practices of a small part of Muslims represented by immigrants from the North Caucasus and Crimea. The article employs Kasper Mathiesen's concept of "traditional Islam" which is based on Talal Asad's anthropological approach to Islam as a discursive tradition. This paper also uses the approach of Barbara Rieffer who explores the relationship between national and religious aspects through the following categories: secular or antireligious nationalism (with no influence of religion), instrumental pious nationalism (which uses religion as an amplification source), and religious nationalism (primarily based on religious identity and rhetoric). In this paper, I conclude that the apolitical Islam of most Ukrainian Muslims can be described through the concept of "traditional Islam," characterized by political conformism and the recognition of Sufism as an integral part of Islamic orthodoxy. The political activism of those Ukrainian Muslims who gravitate towards the Muslim Brotherhood can be described within the framework of B. Rieffer's concept as "instrumental pious nationalism." The militarization of society stemming from the long-term military conflict in eastern Ukraine has led to two main development directions of Islamic political activism in Ukraine: the strengthening of nationalist political discourse and radical political practices.
\end{abstract}

\section{Contact Address}

National Pedagogical Dragomanov University, Turgenivska str. 8-14, Kyiv 01054, Ukraine dbrilyov@gmail.com

\section{Keywords}

Al-Ahbash, Global Muslim Brotherhood, „Traditional“ Islam, instrumental pious nationalism, Islam in Ukraine

Currently, the topic of politics and religion, their relationship and causation are in all probability the most popular in both public and scientific discourses. The factors that led to this state of affairs are not my research aim, although they sometimes serve as the 
necessary context. In my study, I investigate Ukrainian Muslims' political practices based on an analysis of official documents, interviews with Ukrainian ummah leaders and their public statements and media publications.

Before referring directly to the Ukrainian case, it should be noted that researchers often point to a close link between political activism in Islam and nationalism when analyzing political practices in modern Islamic society (E. Evans-Pritchard is often considered the founder of this view with his celebrated study The Sanusi of Cyrenaica) (Evans-Pritchard 1949). There are different opinions about the relationship between religion (including Islam) and nationalism. In his analysis of the connection types between religion and nationalism, Rogers Brubaker identified four main theoretical approaches to the study of their relationship: religion and nationalism are regarded as a similar phenomenon; religions are considered the explanations of nationalism; religion is seen as a part of nationalism; religion is regarded as a variation of nationalism (Brubaker 2012). A. Smith perceives religion as the primary source of the emergence of nationalism, i.e., nationalism has a special language that employs cultural and religious factors for its formation and strengthening (Smith 1981, 64). It is a rather bold definition, as the influence and role of economic, social, and political factors may reinforce the process of nationalist formation or the mood of groups prone to such views cannot be overlooked.

I refer in my study to an approach suggested by B. Rieffer. She suggests distinguishing between the subtypes of interweaving of religious and national through the following categories:

secular or antireligious nationalism (with no impact of the religious factor); instrumental pious nationalism (that uses religion as an amplification factor); religious nationalism (which is primarily built on religious identity and rhetoric) (Rieffer 2003, 224).

The second category, instrumental pious nationalism, deserves special attention because, in my opinion, it is exactly this type of connection between religion and nationalism which is most often employed in the situation in the post-Soviet space, including Ukraine (B. Rieffer regarded this type as inherent for the religious situation in post-Soviet Russia). The peculiarity of instrumental nationalism is that religion is not a major category, but rather an additional element for community unification. It becomes a useful resource for influencing society and the national leaders' electorate's trust. Within this type, religion also serves as a legitimization resource for new state institutions or for maintaining the state's authority and leaders in times of crisis.

It occurs mainly due to influence sources such as language, the sacralization of ancient and modern history and the justification of political plans. A particular appeal to religious grounds on the part of political or national leaders can be traced to crisis times, namely when the economic, military, and social institutions lose their power and religious and national rhetoric comes in handy. Instrumental nationalism differs from religious nationalism 
in the level of the involvement of the religious factor in the nation-building processes. At the instrumental nationalism level, religious institutions and the religious sphere do not achieve such a level of involvement in the political system. Instead, the political system itself uses the dominant religion to unite and develop the national movement (Ibid., 229-230).

Additionally, for my analysis of Ukrainian Muslims' political practices, I turn to the concept of traditional Islam based on the anthropological approach of T. Asad that regards Islam as a discursive tradition (Asad 2009). According to the researcher, Islam is neither a unique social structure nor a heterogeneous set of beliefs, artifacts and customs. In this view, Islam is a tradition that consists of discourses aimed at teaching followers the correct forms and purpose of specific practices. They are established and thus have their history. These discourses are conceptually related to the past (the time when the practice emerged and when the knowledge of its meaning and proper implementation is transmitted) and the future (how the meaning of the practice can best be protected over the short and long term or why it should be modified or abolished) through the present (how it relates to other practices, institutions and social conditions). Orthodoxy plays an essential role here, being more critical for Islam than orthopraxy (Ibid., 20-22).

It was Asad's concept that served as the theoretical basis for K. Mathiesen, who proposed the concept of traditional Islam (Mathiesen 2013). The latter, in his opinion, is one of the dominant concepts in modern Islam. This concept is based on a specific reading of the famous Hadith Jibril, according to which the Islamic religion is divided into Islam, Iman and Ihsan. Each of them represents an anthropological aspect, namely Islam stands for body/practice, Iman for the mind and Ihsan for the spirit/soul), as well as the subfields of identified knowledge, traditions, practices and institutions. This tripartite structure further contextualized the discourse of traditional Islam orthodoxy in three main discursive statement spheres: Islam / Fiqh (Muslim law), Iman / Aqidah (doctrine) and Ihsan / Tasawwuf (Sufism).

The main trope in the traditional Islam narrative about the Islamic past and present is deterioration, collapse and the urgent need for restoration. In all three discursive spheres of conflict, the current state of Islamic science, practice, authority and religiosity are interpreted as disturbed compared to the previous harmonious state. In the Fiqh sphere, the traditional Islam discourse defends and substantiates the institution of the four madhhabs (legal schools) against anti-madhhabism, ${ }^{1}$ reformism and especially Wahhabism/Salafism which is demonized and regarded as an Islamic inner enemy. In the field of Aqidah, the traditions of the two classical doctrine schools, the Ash'ari and Maturidiyya madhhabs, are defended, upheld and viewed as legitimate Islamic orthodoxy, also in opposition to Wahhabism/Salafism.

The third discursive field of conflict is arguably Sufism, this being the most central to traditional Islam's discourse. Sufism is understood not merely as legitimate in Sunni Islam

\footnotetext{
${ }^{1}$ Anti-madhhabism is a general name for movements (mostly within Islamist circles) that view traditional Sunni legal schools as either outdated and not relevant to present, or, conversely, an innovation (Bid'ah) that contradicts primal 'pure' Islam.
} 
but as the heart of Islam and raison d'être of the revelation. The discourse of traditional Islam holistically links the Sufism field with orthodoxy and orthopraxy fields (Iman and Islam). It is exercised in part through accounts of historical deterioration, in which the rise of Wahhabism/Salafism and Western colonial domination are treated as central factors that led to the faulty view among Muslims that Sufism is something extraneous or oppositional to Islam (Mathiesen 2013, 217).

It is noteworthy that in the field of political practice, traditional Islam is positioned as predominantly apolitical, separated from politics, and servile to the existing government, unless the government, of course, is anti-Islamic (See, e.g.: Khalid 2006, 28).

In will argue in this research that these two approaches allow for the best description of the political behavior of Ukrainian Muslims.

\section{Islam and Politics in Ukraine}

When studying Ukrainian Muslim communities, it should be kept in mind that the institutionalized history of Muslims in Ukraine dates back to the end of the nineteenth century, when the first Muslim communities were registered. After 1927, Islam was gradually pushed out of the public sphere. And after 1951 in Soviet Ukraine, Islam is not mentioned in the sphere of public religious life, existing only in the form of underground communities and at the household level. Starting in 1987, and especially with the adoption of the declaration "On the recognition of illegal and criminal acts of repression against peoples subjected to forced resettlement and ensuring their rights," in November 1989 by the Supreme Soviet of the USSR, the mass return of Crimean Tatars from deportation to Crimea (which became part of Ukraine in 1954) began. Accordingly, the number of Muslims in Ukraine began to grow rapidly, especially as the Crimean Tatar repatriates were joined by Meskhetian Turks who fled the escalation of the interethnic conflict in Uzbekistan in 1989. Crimean Tatars and representatives of other Muslim nations were able to register their communities and went out into the public space.

According to the single general census in Ukraine conducted in 2001, the number of Muslims by origin (so-called ethnic Muslims) was 436 thousand, or about $0.9 \%$ of the total population. The largest groups were Crimean Tatars (248 thousand), Volga Tatars (73 thousand), ${ }^{2}$ Azerbaijanis ( 45 thousand), representatives of the North Caucasian ethnic groups (14 thousand), Uzbeks (12 thousand) and Turks/ Meskhetian Turks (ca. 10 thousand).

The largest Muslim community in Ukraine resided in the Crimea (272.6 thousand people, including Sevastopol); the second place was held by the Donetsk region (36 thousand people), followed by a group of regions with the number of people who traditionally profess Islam varying between 10-20 thousand, i.e., Kharkiv (16 thousand), Luhansk (15

${ }^{2}$ The estimate of the Volga Tatars number is debatable, since due to historical reasons (350 years of ethnoconfessional discrimination by the Russian Empire), Volga Tatars were often recorded as Russians or Ukrainians during the census. 
thousand), Dnipropetrovsk (15 thousand), Kherson (14 thousand), Odesa (12.2 thousand), Zaporizhia (11.7 thousand) and the city of Kyiv (10.9 thousand) (Bohomolov et al. 2006, 24).

Before 2013, despite the paucity of the Ukrainian Muslim community, 7 Muslim religious centers were officially registered: the Religious Administration of Muslims of Crimea (Dukhovne upravlinnia musulman Krymu - DUMK) in Simferopol, the Religious Administration of Muslims of Ukraine (Dukhovne upravlinnia musul'man Ukraïny - DUMU) in Kyiv, the Religious Center of Muslims of Ukraine (Dukhovnyi tsentr musulman Ukraïny - DTsMU) in Donetsk, Religions Administration of Independent Muslim Communities of Ukraine "Kievskii Muftiat" (Relibiine upravlinnia nezalezhnykh musul'mans'kykh hromad Ukrainy - RUNMHU) in Kyiv, Religious Administration of Muslims of Ukraine "Umma" (Dukhovne upravlinnia musul'man Ukraïny "Umma" - DUMU-Umma) in Kyiv, Religious Center of Muslims of Crimea (Dukhovnyi tsentr musulman Krymu - DTsMK) in Evpatoria, and All-Ukrainian Religious Administration of Muslims "Unity" (Vseukrains'ke dukhovne upravlinnia musul'man "Yednannia" - VDUM-Yednannia) in Makiyivka, Donetsk region.

As a result of the 2014 events, particularly the annexation of Crimea, DUMK and DTsMK (their members established the Central Religious Administration of Muslims, "Tauride Muftiate" was founded, which has not yet received official registration) found themselves outside the legal field of Ukraine. VDUM-Yednannia and DTsMU remained in the temporarily occupied territories of the armed conflict (in the self-proclaimed, socalled Donetsk People's Republic and Luhansk People's Republic). The rest of the religious administrations (the DUMU mentioned above, DUMU-Umma and RUNMHU "Kievskii Muftiat," as well as the Religious Administration of Muslims of the Autonomous Republic of Crimea, Dukhovne upravlinnia musulman avtonomnoi respubliky Krym - DUM ARK registered in late 2017), and independent Muslim communities that are not part of any of the religious administrations continue to operate in the Kyiv-controlled sovereign territory of Ukraine. I am now going to analyze three ways of combining religion and politics in Ukraine and attempt to answer the question, which of them is most frequent among Ukrainian Muslims.

\section{“Traditional Islam” Guarding an Apolitical Stance}

The most numerous and oldest of those acting within the territory of Ukraine, the Religious Administration of Muslims of Ukraine (DUMU), emerged at the beginning of the independent Ukrainian state. It legitimized the unregistered underground Muslim communities that existed in Ukraine during the Soviet period. From the late 1980s to the early 1990s, the vast majority of them were Volga Tatars (Brylov 2018, 156).

The basic ideological principles of the DUMU are a call to renounce armed jihad, an apolitical stance, and loyalty to Ukraine, of which they are citizens. At the heart of this apolitical nature is the DUMU's connection (at least the ideological one) with the transnational Al-Ahbash movement. The DUMU mufti, Sheikh Ahmed Tamim, a Lebanese by 
birth, is a student of the renowned religious scholar of the twentieth century, the founder and ideologue of al-Ahbash, Abdullah al-Harari al-Habashi, and had his permission (Ijaz) to transfer initiations to two Sufi fraternities (tariqas), Rifa'i and Qadiriyya, as well as teaching his books.

The Al-Ahbash movement itself, also known as the Association of Islamic Charitable Projects (AICP), originated in Lebanon in the early 1980s. Researchers regard it as a specific response of the Sufi community to the aggressive expansion of Islamist organizations in an environment where Sufism was the only possible source of reconstructing the ideological alternative to extremism. One of the probable main reasons for the spread of the movement among Lebanese Sunnis is the fatigue of Lebanese society from the civil war and the search by the Lebanese Sunnis middle class for moderate forms of Islam that would allow Muslims to exist peacefully in multi-religious societies. After fifteen years of civil war and bloodshed, Al-Ahbash's call for religious moderation, political correctness and reconciliation resonated strongly among the middle class, among Sunni intellectuals, professionals, and business people, especially traditional Sunni commercial families in urbanized centers (Hamzeh and Dekmejian 1996, 224). With the fourth wave of migration from Lebanon in 1975-1989, caused by the civil war, the movement spread beyond Lebanon, particularly to Ukraine.

The fundamental theses of the ideology, that consolidated the enclaves of Muslim diasporas who became part of the al-Ahbash network, were the following:

moderation in relations to the host society;

interreligious (primarily Muslim-Christian) dialogue;

an appeal to the Sufi heritage as an integral part of Islam;

an apolitical stance and loyalty to the host state;

extreme intolerance for extremist movements under the religious slogans of Islam.

These ideas were created by people who left Lebanon due to the civil war and interreligious conflicts. Thus, it was the personal experience of the civil war, the interfaith confrontation, that became the social basis for the political behavior that Al-Ahbash's followers demonstrated worldwide. This experience is of particular interest in other multi-religious societies, which explains the authorities' good graces to the movement in several countries. ${ }^{3}$

As it follows from the Al-Ahbash credo, there are several issues crucial to the movement's ideology. First of all, it is its adherence to the Sunnis and the recognition of the four classical Sunni legal schools (madhhabs): Maliki, Hanafi, Shafi'i and Hanbali. The

\footnotetext{
${ }^{3}$ The most famous example of the authorities' appeal to the Al-Ahbash experience is the government's program of "Ahbashism", launched in Ethiopia in response to the strengthening of Islamist, including Jihadist movements, when in religious schools and mosques, representatives of Al-Ahbash retrained about 16,000-18,000 religious leaders of the Ethiopian Muslim community in accordance with the principles of their ideology. See also: Abbink, "Religious Freedom," 353.
} 
movement members refer to themselves as the Shafi' is, a law school common in the Arab countries of the Middle East and the North Caucasus.

In doctrine matters, the movement members refer to themselves as Ash'arites, one of the speculative Islamic theology schools (qalam) and the orthodox Sunni doctrine school. No less important, in the discourse of the movement, is its adherence to Sufism, in particular to the Rifa $i$ Tariqa. Thus, the Religious Administration of the Muslims of Ukraine and the related Al-Ahbash movement can be considered representatives of traditional Islam ('traditional' within the framework of K. Mathiesen's mentioned above). Per the traditional Islam discourse, the political behavior of the DUMU is built, namely a pronounced apolitical stance and loyalty to the current government.

This is specifically articulated in the position of the Al-Ahbash movement founder and teacher of Ahmed Tamim, Abdallah al-Harari: "...we do not think that it is halal [allowed. $-D . B$.] to assassinate heads of government because they judge according to their own laws. We are clean from such ideologies and movements." (Al-Harari 1995, 4).

The head of the DUMU, Sheikh Ahmed Tamim, shares the same vision, emphasizing the distance between the religious and political dimensions of Ukrainian Muslims' life.

We act very prudently because our Muslims are citizens of Ukraine, although most of them originate from the former USSR countries $\langle\ldots>$ We always oppose the use of the religious factor, religious organizations in politics. A particular denomination may be trying to show the government how much the latter needs it, but this is temporary. In order to preserve the unity of the people and guide them in a single direction, politicians and the state have to demonstrate a common strategy. If we all agree that Ukraine is united and multinational, a country where everyone occupies a worthy place, then the state must be at the same distance from everyone. ${ }^{4}$

We do not receive support from anyone. We do not ask for support from anyone. [We do so] merely not to be influenced by political changes in the future. Of course, this is not easy, but it is our firm position that keeps us afloat under any government. ${ }^{5}$

Such an apolitical stance and focus on the orthodoxy construction, 'right' ideas about Islam, is manifested in the texts of Friday speeches (Khutbahs). Having analyzed the texts of 30 speeches from 2012 to 2018, I never came across any policy issues; neither the Palestinian issue nor any other politicized issue was voiced. Instead, the primary attention was always paid to issues of doctrine, Aqidah. In addition, according to traditional Islam discourse, one of the most crucial issues is the criticism of Muhammad ibn Abd al-Wahhab's ideas, the eponymous founder of Wahhabism's reformist trend, and his followers. Sayyid Qutb, an ideologue of Islamism from the Muslim Brotherhood and its organization, along with its genetically related Hizb ut-Tahrir, was also criticized. This was specifically

\footnotetext{
${ }^{4}$ Author's interview, Kyiv, 2016.

${ }^{5}$ Author's interview, Kyiv, 2019.
} 
at almost each of the six congresses of Muslims of Ukraine held by the DUMU in 1994, 1996, 2000, 2006, 2011, and 2018; the issue of uniting Ukrainian society in the fight against terrorism and extremism under religious slogans was one of the main topics.

It is apparent that the personal experience of inter-religious conflict among the Al-Ahbash followers and the orthodox traditional Islam discourse coincided and strengthened each other, giving rise to a kind of radical, or demonstrative, apolitical stance, which is represented in Ukraine by the DUMU.

\section{Political Activism: Between Reformism and Nationalism}

Another kind of political behavior within the Muslim community of Ukraine is represented by two related (both organizationally and ideologically) organizations, namely the All-Ukrainian Association of Civic Organizations "Alraid" and the DUMU-Umma (led by Mufti Sheikh Said Ismagilov).

The "Alraid" (official name: All-Ukrainian Association of Civic Organizations "Alraid") was founded in 1997. It embodies the reformist trend in Ukrainian Islam. It is connected with the global Muslim Brotherhood movement ideologically, organizationally, and financially, primarily with the European organizations considered part of this Islamist network (Brylov 2015, 73-74).

The "Alraid" and the DUMU-Umma have the closest ties with the Federation of Islamic Organizations of Europe ${ }^{6}$ (FIOE) and the European Council for Fatwa and Research. Moreover, on the FIOE Internet resources, DUMU-Umma' muftis Said Ismagilov and former "Alraid" chairman Ismail Kadi are named representatives of this organization in Ukraine. Ismail Kadi and Basil Marii (also former "Alraid" chairman) were also present as delegates at the First FIOE General Congress on 23-26 January 2020, in Istanbul, where it was decided to rename the FIOE to the "Council of European Muslims" (CEM).

Samir Falah, the current chairman of the Council of European Muslims (formerly FIOE), was present at the 2016 election of the next "Alraid" chairman. He greatly influenced the appointment of a Crimean Tatar (Seyran Arifov), not an Arab (usually a Palestinian Arab), that has always been the case before. Accordingly, one can assume that there was existing coordination between the Muslim Brotherhood's European organizations and their Ukrainian counterparts from the "Alraid" and the DUMU-Umma. A large number of the "Alraid" and the RAMU "Umma" charitable projects are supported by foundations related to the Muslim Brotherhood; in particular, in different years, the funding came from WAMY (The World Assembly of Muslim Youth), Islamic Relief, and MuslimeHelfen (a charity associated with the German Muslim Brotherhood branch, see: PRO 2009), and other Islamist foundations.

Due to its charitable organization status, the „Alraid“ could not register as another muftiate in Ukraine. To solve this problem in 2008, the DUMU-Umma was established,

${ }^{6}$ Since 2020 - Council of European Muslims. 
which is largely a proxy muftiate for the „Alraid“ in Ukraine. A similar connection is indicated by the fact that the DUMU-Umma imams take part in the General Assembly of the „Alraid," while the representatives of the „Alraid“ are also members of the DUMUUmma structural units (in particular, the „Alraid“ chairman Seyran Arifov is a member of the DUMU-Umma Sharia Committee).

Turning to the political discourse analysis of these two organizations, it should be noted that the „Alraid“ representatives demonstrate intense political activism, the desire to be incorporated into the government agencies to create a political lobby. In particular, the "Alraid“ is actively working with various political parties, trying to achieve representation in the government. As the former „Alraid“ head, Ismail Kadi stated in an interview: „...we have not yet reached this level [of representation in government. - D.B.], despite our cooperation with many parties." (Kadi 2010).

It is also difficult to single out the guiding principle of the "Alraid" and DUMU-Umma representatives and follow the chosen political forces to cooperate with. Among their contacts, one can see the representatives of the pro-Russian "Ukrainian Choice" of Viktor Medvedchuk; the head of the nationalist "Brotherhood" Dmytro Korchynsky; representatives of the Crimean Tatar Majlis and "Petro Poroshenko's Bloc" Refat Chubarov and Mustafa Dzhemilev. A representative of the DUMU-Umma was seen at the "Unity Forum" of the center-right "All-Ukrainian Association Batkivshchyna" (led by the former Prime Minister of Ukraine Yulia Tymoshenko) on 22 January 2019. It seems that the political strategy of the "Alraid" and DUMU-Umma is dominated by political pragmatism.

In the meantime, the probability that any political force with an Islamic agenda could form seems extremely unlikely, primarily due to a reasonably stable Islamophobia in Ukrainian society. According to Vyacheslav Likhachev, the Head of the Group for Monitoring the Rights of National Minorities, Islamophobia is one of the most relevant xenophobia forms in Ukraine (Likhachev 2012). According to last year's Pew Research Center, only $25 \%$ of Ukrainians would agree to having a Muslim as a member of their family, one of the lowest numbers in Eastern and Western Europe (even in Russia, where systematic persecution of certain groups of Muslims exist, this indicator is 34\%) (Pew Research Center 2018). The low probability of success of an „Islamic“ political project in Ukraine is confirmed by the outcomes of the early parliamentary elections held in 2014. The attempt by the most media-popular representatives of the Ukrainian Muslim community, Said Ismagilov, and Amina Okueva, to convert their media capital into a political one failed. The „Ukraine is a United Country“ party, in which Said Ismagilov was in the top five, obtaining only $0.12 \%$ of the votes. Amina Okuyeva, who ran in the municipal elections in Odessa, received only $3.72 \%$ of the votes. (Brylov 2016, 278)

In general, political activism is of great importance in the activities of the DUMUUmma Mufti, Sheikh Said Ismagilov. Analyzing the political discourse formed by him, one can see its orientation towards nationalist rhetoric. ${ }^{7}$ Said Ismagilov's particularly na7 See more on the DUMU-Umma nationalist discourse: Denys Brylov, "Islam in Ukraine: The Language
Strategies of Ukrainian Muslim Communities." Religion, State \& Society 46, no. 2 (2018): 156-173. 
tionally marked rhetoric became apparent after the Kyiv Maidan events, the annexation of Crimea, and the anti-terrorist operation in Eastern Ukraine. One can assume that the appeal to nationalist discourse is connected with the Russian-Ukrainian conflict and the loss of a significant part of the Ukrainian ummah (i.e., Crimean Muslims and Muslims of Eastern Ukraine). The analysis of the speeches of the DUMU-Umma Mufti leads, however to conclusions that from the very beginning, the new Mufti chose not merely patriotic, but predominantly nationalist, rhetoric: “... You know, they will be afraid of us. They will be frightened and respect us. Because we are a country that has managed to reconcile different peoples, different religions, in order to create one super-ethnos, one Ukrainian nation." (DUMU-Umma... 2014)

Some of Said Ismagilov's speeches make it possible to relate the political discourse he forms to the postmodernist one, the distinctive features of which are irony as the main trope and the relativism and instrumentalism that stem from it. ${ }^{8}$ In particular, speaking at the presentation of the Ukrainian translation of the text of the Quran at the Muhammad Asad Islamic Cultural Center in Lviv, Said Ismagilov noted that "... Islam is characterized by inculturation, so the next edition of the Quran in Ukrainian may be published in black and red," (Koran yak shlyakh 2015, 6), thus referencing the black and red flag of Ukrainian nationalists and desecrating, instrumentalizing the Quran.

Said Ismagilov's assessment of the number of Ukrainian Muslims and "Alraid" representatives is no less postmodernist "irony" and relativistically variable from interview to interview. As no research on the number of Muslims in Ukraine has been conducted, and all calculations are based on the All-Ukrainian Census of 2001, any estimate of the number of Muslims in Ukraine is speculative, as used by these speakers, who voice different numbers in different interviews, depending on situational needs. It is therefore not surprising that, for example, Said Ismagilov's estimate of the number of Muslims in Crimea may change twice in various interviews - from 600 to 300 thousand, and the total number of Ukrainian Muslims will range from 1 to 1.5 million (all cases consider annexed Crimea and temporarily occupied territories of Ukraine) (See, e.g., Ismagilov 2012, Ismagilov 2015, Kadi 2010).

It can be assumed that the choice of nation-oriented rhetoric is primarily related to the attempt to find a niche in the Muslim community of Ukraine, as well as to the confrontation between the DUMU-Umma and its main competitor in the Muslim community of Ukraine,

\footnotetext{
${ }^{8} \mathrm{~V}$. Kuznetsov writes very aptly about the modern Islamists' inclination to postmodernist political discourse: “... Islamists from Al-Nahda, whose political vision may seem romantic at first glance, were in reality almost the quintessence of postmodernism. Incessantly speaking of human rights, democracy, freedom, social and political justice, the Al-Nahda adepts demonstrated excellent command of the liberal-democratic vocabulary. At the same time, quoting the Quran and the Sunnah of the Prophet to other followers, quoting their speeches with references to the works of al-Tawheed, Sayyid Qutb, al-Maududi, Hassan al-Banna, and other pillars of Salafi thought, they seemed to confess the insincerity of their own appeals of freedom and democracy." See.: Vasilii Kuznetsov. Poetika politiki: tunisskiy variant [The Poetics of Politics: the Tunisian Version]. Moskva: Institut vostokovedeniya RAN, 2013: 22.
} 
the Religious Administration of Muslims of Ukraine (DUMU) led by Ahmed Tamim. The DUMU has many more followers and much more authority outside Ukraine. This kind of nationalist discourse makes it possible to classify the "Alraid" and the DUMU-Umma as representatives of reformist circles, whose reformism is "sometimes indistinguishable from nationalism," to quote from E. Gellner (Gellner 1985, 8).

In 2017, the DUMU-Umma initiated the adoption of the "Charter of Muslims of Ukraine" and the "Social Concept of Muslims of Ukraine." These documents covered, in particular, the issue of Islam and politics. Here for example, is what the "Charter" says in "Islam and the modern Ukrainian society":

"Muslims of Ukraine as active citizens are allowed to participate in the country's political life, as citizenship involves political activity in terms of participation in both the voting and political institutions of the country (government institutions)." (Ukrainian Muslims Charter 2016)

In the "Social Concept," the corresponding chapter includes the following sections: "Islam and the State," "Muslim Minorities in Secular States," "Islam and Civil Society," and "Islam and Patriotism." In addition, the first lines of this chapter identify clearly that the authors of the concept have ties to the Islamist circles: "The Islamic understanding of the state and statehood arose in the Muslim community of the time of the Prophet Muhammad (peace and blessings of Allah be upon him) and the righteous caliphs." (DUMU-Umma 2019). The idea that an "Islamic state" was created in the Prophet Muhammad's time is also a hallmark of the reformist trend and borrowing from Orientalist ideas about Islam.

As J. Casanova points out, "paradoxically, modern Islamists have adopted from Western orientalists the vision of a 'symbiosis' of religion and politics in the prophetic charismatic age and so their calls for religious revival are often accompanied today by calls for the establishment of an Islamic state." (Casanova 2001, 1055). The borrowing of Orientalist, Western-originated views is evidenced by the fact that in his speeches, DUMU-Umma Said Ismagilov sometimes calls the Prophet Muhammad "founder of Islam" (Didula 2014), which certainly contradicts the orthodox discourse of traditional Islam, which views Muhammad as the last Muslim Prophet, and in no way its founder.

At the same time, despite the patriotic and sometimes nationalist rhetoric, it can be argued that nationalism in the political discourse of Ukrainian Islamists is instrumental. It is designed to strengthen authority in a society where a loudly stated patriotic or even nationalist stance makes it possible to defend oneself against any accusations. Despite the public 'nationalism' of the discourse, Said Ismagilov remains closely associated with Russian-speaking Islamic discourse. In particular, he collaborates with the website of Russian-speaking Muslims, Alif-TV. It is noteworthy that in the section "Our Ummah" ("Our Community"), this site presents mainly the regions of Russia, as well as Ukraine and Moldova, and the channel's policy is to identify Russian-speaking Muslims with the Russian Ummah, promoting the idea of their commonality: 
"The AlifChannel is $\langle\ldots>$ for everyone who speaks Russian. Our team is the brightest and most creative. The best journalists and prominent media figures of the Russian ummah $\langle\ldots\rangle$ "AlifTV" - everything about the life of Muslims on 1/6 of the globe $<\ldots .>$ "Alif" - the media mirror of the Russian ummah." (Alif-TV 2018)

This indicates that Said Ismagilov's nationalist Ukrainian-language discourse is aimed primarily at non-Muslims, patriotic citizens of Ukraine, and a relatively small group of ethnic Ukrainians who have converted to Islam and are very active in the public sphere.

This political discourse also instrumentalizes the phraseology of Christian origin, imitating the controlling functions of the imperial muftis. The official website of the DUMU-Umma uses, for example, the following wording: "The Religious Administration of Muslims of Ukraine "Umma" is in canonical unity with the Religious Administration of Muslims of Crimea" (DUMU-Umma 2018) The concept of "canonical unity" is borrowed from the Russian Orthodox Church's (ROC) rhetoric, which claims canonical unity with the Ukrainian Orthodox Church. According to A. Bustanov and M. Kemper, "the use of such "Christianizing equivalents" for Muslim concepts goes back to the establishment, by Catherine the Great, of state-appointed Muftiates in Imperial Russia; Soviet and post-Soviet Muftiates by and large inherited their functions of trying to control Muslim communities." (Bustanov and Kemper 2013, 270).

Given the pronounced instrumental nature of the "Alraid's" political discourse, and especially their proxy muftiate of the DUMU-Umma, one can assume that we are dealing with manifestations of instrumental pious nationalism, according to B. Rieffer. In it, religion (Islam in this case) is not the major category. It instead serves as an ancillary element to consolidate its supporters, becoming a useful resource for influencing society during a crisis, and for gaining an advantage in competing in the religious market with its ideological opponents from the Religious Administration of Muslims of Ukraine led by Mufti Sheikh Ahmed Tamim. Describing the political discourse of these organizations, one can talk about a kind of blurred 'diffused' political activism.

\section{Radical Political Activism}

Supporters of radical forms of political activism, in particular jihadism, have also recently received their representation in the Ukrainian Muslim community. The most interesting phenomenon was the Volunteer Battalion "Separate Hundred 'Crimea'," staffed mainly (although not exclusively) by Muslims from Crimean Tatars who left Crimea after the annexation of the peninsula by Russia, as well as Ukrainians who converted to Islam. Most of the fighters of this military formation were supporters of Salafism. Among the 'Muslim' volunteer military groups, one should also note the Sheikh Mansour Battalion, the Dzhokhar Dudayev Battalion and the Noman Çelebicihan Battalion.'

\footnotetext{
${ }^{9}$ See more about the controversial ties of these military groups with the Syrian and Iraqi jihadists.: Oliver Boyd-Barrett, Western Mainstream Media and the Ukraine Crisis: A Study in Conflict Propaganda. New York:
} 
These volunteer groups' principal motivation was the fight against Russia and proRussian forces, associated with anti-Islamic or anti-Chechen policies. Militant hundreds viewed the military actions against the separatists as a defensive jihad (Jihad Al-Dafaa).

Here is what the website of "Separate Hundred 'Crimea" states:

"...Muslims of Ukraine view this war a defensive jihad (Holy War). Muslims of Ukraine, represented by the Separate Hundred 'Crimea', took up arms for their homeland to protect themselves and their compatriots, to protect their families and loved ones, to protect their honor and property, as well as the honor and property of their fellow citizens, regardless of their religion or nationality. Muslims from the 'Crimea' Hundred are ready to defend the natural right to freely profess their religion, the right that the Ukrainian state gave to Muslims in full. And the Muslims of Russia do not have such a right today." (Dobrovolchiy batalyon 'Krym' 2014)

The reason for such sentiments, among representatives of radical political activism, lies primarily within the liberal religious legislation of Ukraine, which has no options for the prohibition of specific religious organizations, or a list of extremist literature, etc. Hizb ut-Tahrir communities openly operated in Ukraine, for example, holding international congresses of their party in Crimea; Salafi communities and organizations from the Muslim Brotherhood network also operated unhindered. After the annexation of Crimea, the religious situation on the peninsula deteriorated sharply: raids on mosques and madrassas began, and a media campaign was launched against the ideologies banned in Russia, namely Salafism, Hizb ut-Tahrir, Nurjular, and others. Only those organizations that took a loyal pro-Russian position remained in the religious field.

The formation of radical political practices among Ukrainian Muslims did not go unnoticed by international jihadist movements. Abdul Karim Krymsky, who headed the Crimean Tatar Jamaat (combat detachment) consisting of Jaish al-Muhajirin val-Ansar, called on Crimean Tatars in a video message released in May 2014 to "remember their ancestors who took tribute from Moscow" and "embark on the path of jihad" against Russia. At the same time, in his address, he likened Ukraine and Russia as territories on which 'infidels' humiliate Muslims. In his view, it does not make sense for Crimean Tatars to turn to international organizations, and they should start an open war with infidels: "We see that Muslims and Tatars who left for Ukraine are in a humiliating position, while here [in Syria] Muslims walk freely with their heads held high, we just see the difference $<\ldots>$ we ask Allah to lead the Tatar Crimea, the Tatars, the people of Crimea on this path [of jihad], and that we work together to establish the laws of Allah on this land." (Akhbar Sham 2014).

Ukraine has recently been attracting more and more supporters of radical political activism, becoming a sort of "logistic base." In particular, there are illegal migration channels from Turkey to Ukraine with further transit to the EU of former militants, so-called 
Islamic State fighters, and representatives of Syrian armed anti-government groups (including Jabhat al-Nusra, etc.). ${ }^{10}$

According to a representative of the Muhajirun ${ }^{11}$ movement, Turkey offered a third safe country of choice to persons with Russian citizenship (or from post-Soviet countries in general) who were deported on suspicion of involvement in terrorist activities, so that the main burden fell on Georgia and Ukraine (Tuaev 2016).

According to the estimates of the former militants of the so-called "Islamic State", there may be several hundred combatants that took part in hostilities in Syria and Iraq. According to my informants, who are in contact with the above-mentioned circles, the number of former militants can amount to more than a thousand people. ${ }^{12}$ Several factors facilitate the concentration of illegal jihadists in Ukraine (mostly from the countries of the former Soviet Union), some of them are the following:

\section{Russian is widely used in Ukraine.}

The belief that Ukraine does not extradite foreigners to their countries of origin.

An idea about the neutral stance towards Muslims (as I have shown above, it is far from being true).

Ease in getting fake I.D.s to move freely.

As noted by V. Pakhomenko, former analyst of the program for Europe and Central Asia of the International Crisis Group, people from the North Caucasus fought on the side of the Ukrainian army, and among them were those who gained their combat experience in Syria. At the beginning of the armed conflict in Eastern Ukraine, when volunteers went there to fight, there was a demand for experienced fighters (Magomedov 2017).

According to Abu Mansur Nogaisky, the Nogai diaspora leader in Turkey, Ukraine is a temporary shelter for those arrested and deported from Turkey (Sergatskova 2017). The presence of carriers of radical political practices undoubtedly influences Ukrainian Muslims' political behavior in some way. Only time will tell how profound and steady this influence will be. I agree to some extent with the view of the already mentioned Abu Mansur Nogaisky that they do not directly threaten Ukraine:

"Ukraine is not at war anywhere. Should Ukraine participate in a military operation in Syria as part of a coalition, there would be a threat. But who knows what they will want? They can do something on their own. Although ISIS does not plan this, there are individuals who can do something for them. But neither the 'Emirate of the Caucasus', nor Al Qaeda,

\footnotetext{
${ }^{10}$ It is noteworthy that the illegal migration channel from the Middle East to Kyiv via Turkey has existed since late Soviet times and has continued to operate during Ukraine's independence. See: Bler Rubl and Olena Malynovska, ed., 'Netradytsiini' immihranty u Kyievi ["Non-Traditional” Migrants in Kyiv] (Kyiv: VD “Stylos", 2003), 72.

${ }^{11}$ The Muhajirs are immigrants from Russia to Turkey for religious reasons. Originally, the term meant Muslim immigrants from Mecca to Medina during the preaching of the Prophet Muhammad.

${ }^{12}$ Author's interview, Kyiv, 2019.
} 
nor ISIS view Ukraine as a place for terrorist attacks. Although it is not a Muslim country, they can feel safe there. The fact that many of them are arming themselves is most likely true. I heard that one of them [ISIS-fighters] is engaged in debt-collecting activities. Ukrainians come to them, they say, we can't repay our debt - they go and return it. Of course, they do not use violence, but when bearded people come with weapons... I know for sure that they do it. At least they say so themselves. However, in Ukraine today, a man with a weapon is not uncommon." (Ibid.)

The presence of jihadists, who took part in the hostilities in Syria and Iraq, within the territory of Ukraine also has negative consequences for Ukraine's international image. This vulnerability is highlighted by the scandals that occasionally revolve around this issue in the Western media (Skliarevskaia 2017). Therefore, from the strategic perspective, this unresolved issue may pose a serious problem.

\section{Conclusions}

Summing up my research, I believe that there are several forms of political activity in the Islamic society of Ukraine that certain groups of Ukrainian Muslims demonstrate. Among them are:

A demonstrative apolitical stance (the leading representative is the Religious Administration of Muslims of Ukraine, DUMU);

"Diffused" political activism (the All-Ukrainian Association of Civic Organizations "Alraid" and its proxy muftiate, DUMU-Umma);

Radical forms of political activism (autonomous communities of supporters of the "Islamic State," as well as, with some reservations, representatives of "Muslim" volunteer battalions).

Recently, stemming from the militarization of society under the influence of the protracted military conflict in the east, the development of Islamic political activism in Ukraine has mainly taken place in two main areas:

- strengthening nationalist political discourse

- radical political practices.

The form of political activism of Ukrainian Muslims, in which one can distinguish nationalist tendencies, can be described within the theoretical framework of B. Rieffer as instrumental pious nationalism.

The apolitical nature of most Ukrainian Muslims, who mainly belong to the Religious Administration of Muslims in Ukraine (DUMU), is related to the orthodox discourse of traditional Islam. It is precisely this appeal to traditional Islam practices, closely related to the Sufism widespread among the majority of Muslim peoples, whose representatives 
make up the Ukrainian Muslim community, which enables the DUMU to maintain its powerful mobilization potential.

A clear example of this mobilization potential is the last two congresses of Ukraine's Muslims held by the DUMU. Each of them gathered more than 3.5 thousand delegates. None of the Muslim structures competing with the DUMU has demonstrated thus far such mobilization potential. Simultaneously, the apolitical nature of the 'silent' majority leaves room for political activists to try to speak on behalf of Ukraine's Muslims. Therefore, the competition for the right to speak on behalf of the Muslims of Ukraine will continue.

\section{Bibliography}

Abbink, Jon. "Religious Freedom and the Political Order: the Ethiopian 'Secular State' and the Containment of Muslim Identity Politics.” Journal of Eastern African Studies 8, no. 3 (2014): 346-365.

Akhbar Sham. "Amir Salakhaddin Shishani i naib Abdul Karim Krymskiy: 'O Leramone. Kryme i Dzhikhade’.” [Amir Salahaddin Shishani and Naib Abdul Karim Krymsky: 'About Leramon, Crimea and Jihad']. Akhbar Sham, May 13, 2014. https://web.archive.org/web/20150223195200/http://www.akhbarsham. info/2014/05/13/53/

Al-Harari, Abdallah. "My derzhimsya veroy vsekh imamov." [We Hold Out on by the Faith of All Imams]. Minaret 17 (1995): 4.

Alif-TV. “O nas.” [About Us]. Accessed May 10, 2018. https://alif.tv/about-us/

Asad, Talal. "The Idea of an Anthropology of Islam." Qui Parle 17, no. 2 (2009): 1-30.

Bogomolov Alexandr, Danilov Sergii, Semivolos Igor and Galina Yavorskaya. Islamskaya identichnost v Ukraine [Islamic Identity in Ukraine]. Kiev: VD "Stilos”, 2006.

Boyd-Barrett, Oliver. Western Mainstream Media and the Ukraine Crisis: A Study in Conflict Propaganda. New York: Routledge, 2016.

Brubaker, Rogers. "Religion and Nationalism: Four Approaches." Nations and Nationalism 18, no. 1 (2012): 2-20.

Brylov, Denys. "Islam in Ukraine: The Language Strategies of Ukrainian Muslim Communities." Religion, State \& Society 46, no. 2 (2018): 156-173.

Brylov, Denys. "Transformed Perceptions of Islam and Muslims in Ukraine in the Wake of the Social and Political Changes Caused by Euromaidan." In Islam, Religions, and Pluralism in Europe, edited by Ednan Aslan, Ranja Ebrahim and Marcia Hermansen, 267-84. Wiesbaden: Springer VS, 2016.

Brylov, Denys. "Ukrainian Modernist Groups in an International Context." Anthropology \& Archeology of Eurasia 53, no. 3 (2015): 72-80.

Bustanov, Alfrid and Michael Kemper. "The Russian Orthodox and Islamic Languages in the Russian Federation.” Slavica Tergestina 15 (2013): 258-277.

Casanova, Jose. "Civil Society and Religion: Retrospective Reflections on Catholicism and Prospective Reflections on Islam.” Social Research 68, no.4 (2001): 1041-1080.

Didula, Petro. "International Conference 'Nostra Aetate' 50-littia khrystyiansko-islamskoho dialohu: zdobutky, vyklyky ta perspektyvy.” [International Conference 'Nostra Aetate' 50th anniversary of Christian-Islamic 
dialogue: achievements, challenges and prospects]. YouTube, April 9, 2014. https:/www.youtube.com/ watch?v=jXbWEv0OxX0

Dobrovolchiy batalyon 'Krym'. "Segodnya flag Ukrainy - eto flag spravedlivosti!!!” [Today the Flag of Ukraine is the Flag of Justice]. Last modified July 27, 2014. http://battalionkrym.blogspot.ru/2014/07/ blog-post_10.html\#more

DUMU-Umma. "DUMU-Umma oholoshuie pro pochatok Ramadanu." [DUMU-Umma Announces the Beginning of Ramadan]. Accessed May 10, 2018. https://umma.in.ua/ua/node/1417

DUMU-Umma. “Muftii DUMU ‘Umma’ v efiri 5 kanala v peredache 'Edyna Rodyna'.” [Mufti

DUMU 'Umma' in the 5 Channel's show 'Yedyna Rodyna' (United Family)].” YouTube, November 3, 2014. https://www.youtube.com/watch?v=CqirLsSb3yA. 11:52.

DUMU-Umma. "Sotsialna kontseptsiia musulman Ukrainy." [Social Concept of Muslims of Ukraine]. Accessed June 10, 2019. https://umma.in.ua/ua/node/1890

Evans-Pritchard, Edward. The Sanusi of Cyrenaica. Oxford: Clarendon, 1949.

Gellner, Ernest. “Introduction.” In: Islamic Dilemmas: Reformers, Nationalists and Industrialization, edited by Ernest Gellner, 1-9. Berlin: Mouton De Gruyter, 1985.

Hamzeh, Nizar and Hrair Dekmejian. "Sufi Response to Political Islamism: Al-Ahbash of Lebanon." International Journal of Middle East Studies 28 (1996): 217-229.

Ismagilov, Said. "Musulmane v Donbasse. Interviyu s muftiyem Saidom Ismagilovym.” [Muslims in Donbass. Interview with Mufti Said Ismagilov]. Ostrov, May 29, 2012.

http://www.ostro.org/general/society/articles/400572/

Ismagilov, Said. "Ukraina ye spadkoiemtsem dukhovnoi tradytsii Krymskoho khanstva." [Ukraine is the Heir to the Spiritual Tradition of the Crimean Khanate]. Islam v Ukraini, March 31, 2015. http://islam. in.ua/ua/print/9061

Kadi, Ismail. "Al-Hukūmāt Wālhay'āt Al-Islāmiyya Al-'halījiyya Tuqaddimu Lanā Malyūn Dūlār Sanawiyan.” [Gulf Governments and Islamic Organizations Provide Us With One Million Dollars Annually]. Al-Seyassah, June 26, 2010. https://web.archive.org/web/20100628041007/http://www.al-seyassah.com:80/AtricleView/ tabid/59/smid/438/ArticleID/95238/reftab/59/Default.aspx

Khalid, Adeeb. Islam after Communism: Religion and Politics in Central Asia. Berkeley: University of California Press, 2006.

"Koran yak shliakh do mizhkulturnoho ta mizhrelihiinoho dialohu." [The Koran as a Path to Intercultural and Interreligious Dialogue]. Umma 25 (2015): 6.

Kuznetsov, Vasilii. Poetika politiki: tunisskiy variant [The Poetics of Politics: the Tunisian Version]. Moskva: Institut vostokovedeniya RAN, 2013.

Likhachev, Vyacheslav. "Islamofobia v Ukraine: novie tendentsii." [Islamophobia in Ukraine: New Trends]. Historians, February 27, 2012. http://www.historians.in.ua/index.php/en/ doslidzhennya/154-viacheslav-lykhachev-yslamofobyia-v-ukrayne-novye-tendentsyy

Magomedov, Zakir. "V Kiev, gde ne presleduyut salafitov." [To Kiev, Where Salafis Are Not Persecuted]. Kavkaz.Realii, June 14, 2017. https://www.kavkazr.com/a/v-kiev-gde-ne-presleduyut-salaftov/28548032.html

Mathiesen, Kasper. “Anglo-American 'Traditional Islam' and Its Discourse of Orthodoxy.” Journal of Arabic and Islamic Studies 13 (2013): 191-219. 
Pew Research Center. "Eastern and Western Europeans Differ on Importance of Religion, Views of Minorities, and Key Social Issues." Pew Research Center, October 29, 2018.

https://www.pewforum.org/2018/10/29/eastern-and-western-europeans-differ-on-importance-of-religionviews-of-minorities-and-key-social-issues/

PRO. “Islamische Netzwerke: Spenden für den Terror?” PRO, June 16, 2009. https://www.pro-medienmagazin. de/medien/fernsehen/2009/06/16/islamische-netzwerke-spenden-fuer-den-terror/

Rieffer, Barbara-Ann. "Religion and Nationalism. Understanding the Consequences of a Complex Relationship.” Ethnicities 3, no. 2 (2003): 215-242.

Rubl, Bler and Olena Malynovska, ed., 'Netradytsiini' immihranty u Kyievi [“Non-Traditional” Migrants in Kyiv] (Kyiv: VD "Stylos", 2003).

Sergatskova, Kateryna. "Na shliakhu z IDIL: yak kolyshni boiovyky 'Islamskoi derzhavy' opyniaiutsia v Ukraini." [On the Way to ISIS: How Former Islamic State Militants Find Themselves in Ukraine]. Hromadske, July 11, 2017. https://hromadske.ua/posts/kolishni-boioviki-islamskoi-derzhavi-v-ukraini

Skliarevskaia, Gala. "IGIL. Sky News i korruptsionnyy khab." [ISIS, Sky News and the 'Corruption Hub']. Detektor-Media, September 2, 2017. https://detector.media/infospace/article/ 129498/2017-09-02-igil-sky-news-i-korruptsionnyi-khab/

Smith, Anthony. The Ethnic Revival in the Modern World. Cambridge: Cambridge University Press, 1981.

Tuaev, Magomed. "Eksperty: dlya obosnovavshegosya v Turtsii chechenskogo podpolia vozrastayut riski pokusheniy i ekstraditsii." [Experts: Risks of Assassination and Extradition are Growing for the Chechen Underground Settled in Turkey]. Kavkazskiy Uzel, July 7, 2016. http://www.kavkaz-uzel.eu/articles/285362/

“Ukrainian Muslims Charter.” Islam in Ukraine, December 5, 2016. https://islam.in.ua/en/society/ ukrainian-muslims-charter 